\title{
Correspondence
}

To the Editors

\section{Multisystem inflammatory syndrome in children: Danger of over-diagnosis}

Sri Lanka Journal of Child Health, 2021: 50(4): 744

DOI: http://doi.org/10.4038/sljch.v50i4.9906

(Key words: MIS-C, Covid-19)

Dear Editors,

COVID-19 has caused a lot of direct and indirect effects on the paediatric population. Though the virus, fortunately, is not so damaging to children unlike adults, multisystem inflammatory syndrome in children (MIS-C) is a known, uncommon but potentially lethal complication in children. The defining criteria for MIS-C include evidence of recent COVID infection, like COVID antibody or Reverse Transcription Polymerase Chain Reaction (RT-PCR) and even a clinical history of COVID, in cases presenting with fever and multiorgan $(>2$ organ systems) dysfunction, with no other possible explanation ${ }^{1,2}$. The problem is that in developing countries, many children get complicated with multi-organ involvement due to other especially bacterial causes and often, investigations like cultures take a back seat ${ }^{3}$. Even when performed, due to various reasons, cultures are negative in clinical septicaemia cases ${ }^{4}$. Moreover, aetiological agents like scrub typhus, which are notorious to cause systemic involvement, also do not grow in cultures. Their specific lab diagnosis is not available widely, in an easy fashion even today ${ }^{5}$.

All over the developing world, many kids have already been infected with COVID-19, and demonstrate antibodies on testing. As a result, a challenge for the healthcare community is the overdiagnosis of MIS-C in sick hospitalized children, in low resource countries. Possible fallouts are 1) more expense of investigations 2) increased demand for expensive medicines e.g. immunoglobulin 3) overlooking basic morbidity in many cases, 4) unwanted psychological trauma to parents, and above all 5) wrong labeling of MISC in many affected children. It is high time, the scientific community thinks on redefining MISC in low resource situations with high COVID positivity, in a way, which is actually reflective of MIS-C, and helps in avoiding the negative impact due to over-diagnosis of the same.
References

1. Information for Healthcare Providers about MIS-C. Centre for Disease Control, Atlanta. 2020. [updated 2020, cited 2021 May 19, 2021] available from: https://www.cdc.gov/mis-c/hcp/

2. Multisystem inflammatory syndrome in children and adolescents temporally related to COVID-19. World Health Organization, Geneva. 2020. [updated 2020, cited 2021 May 19, 2021] available from: https://www.who.int/newsroom/commentaries/detail/multisysteminflammatory-syndrome-in-children-andadolescents-with-covid-19

3. Viswanathan R, Singh AK, Ghosh C, Dasgupta S, Mukherjee S, Basu S. Profile of neonatal septicaemia at a district-level sick newborn care unit. Journal of Health, Population and Nutrition 2012; 30(1): 41-8. https://doi.org/10.3329/jhpn.v30i1.11274 PMid: 22524118 PMCid: PMC3312358

4. Lever A, Mackenzie I: Sepsis: definition, epidemiology, and diagnosis. BMJ 2007; 335: $879-83$.

https://doi.org/10.1136/bmj.39346.495880 .AE

PMid: 17962288 PMCid: PMC2043413

5. Prakash JAJ. Scrub typhus: risks, diagnostic issues, and management challenges. Research and Reports in Tropical Medicine 2017; 8: 73-83. https://doi.org/10.2147/RRTM.S105602 PMid: 30050348 PMCid: PMC6038894

Baljeet Maini

Professor of Paediatrics, Teerthankar Mahaveer Medical College and Research Centre, Moradabad, India

*Correspondence: mainibaljeet@gmail.com

iD https://orcid.org/0000-0002-1265-8534

The author declares that there are no conflicts of interest.

Open Access Article published under the Creative Commons

Attribution CC-BY C. (†) License 